\title{
Aging of air pollution control residues from municipal solid waste incinerator: Role of water content on metal carbonation
}

\author{
Pin-Jing $\mathrm{He}^{\mathrm{a}, *}$, Qun-Ke Cao ${ }^{\mathrm{a}}$, Li-Ming Shao ${ }^{\mathrm{a}}$, Duu-Jong Lee ${ }^{\mathrm{b}}$ \\ ${ }^{a}$ State Key Laboratory of Pollution Control and Resources Reuse, Tongji University, Shanghai 200092, China \\ ${ }^{\mathrm{b}}$ Chemical Engineering Department, National Taiwan University, Taipei, Taiwan, 10617
}

Received 4 March 2005; accepted 6 June 2005

Available online 5 July 2005

\begin{abstract}
This work studies the effect of water content on the aging of APC residues, with a liquid to solid ratio $(L / S)$ of 0.25 or 10 , aged with or without exposure to ambient air. After the residue was mixed with water, $\mathrm{CaSO}_{4}$ and $(\mathrm{Na}, \mathrm{K}) \mathrm{Al}_{3}\left(\mathrm{SO}_{4}\right)_{2}(\mathrm{OH})_{6}$ in the raw sample yielded ettringite. When $\mathrm{CO}_{2}$ were available, this ettringite was further transformed to gypsum, calcite and possibly gibbsite. Experimental data revealed that the concentrations of $\mathrm{Pb}, \mathrm{Zn}, \mathrm{Cd}, \mathrm{Hg}$, and $\mathrm{Cu}$ fell with age, whereas that of $\mathrm{Cr}$ increased. Given $L / S=10$, excess $\mathrm{Ca}^{2+}$ ions were present in the suspension, so a precipitate of primarily calcite crystals of sizes under $5 \mu \mathrm{m}$ formed on the air-water surface. This layer significantly reduced the rates of decline of $\mathrm{Pb}, \mathrm{Zn}, \mathrm{Cd}$ and $\mathrm{Hg}$ contents, and also reduced the increasing rate of $\mathrm{Cr}$ content in the suspension. This result follows from the mass transfer barrier of $\mathrm{CO}_{2}$ added at the air-water surface and the occurrence of subsequent chemical reactions in the suspension. An estimate of the mass transfer rate revealed that the rate-controlling step with $L / S=10$ was the dissolution and diffusion of $\mathrm{CO}_{2}$ in the bulk solution. However, at $L / S=0.25$, the rate-limiting step was the dissolution of metals from ash particles. Water content is a very important process factor, whose distribution in the sample, and the resulting competition between carbonate ion flux and heavy metal flux, govern the reaction time required during the natural aging process.
\end{abstract}

(C) 2005 Elsevier B.V. All rights reserved.

Keywords: Municipal solid waste incinerator; Air pollution control residues; Aging; Carbonation

\section{Introduction}

Air pollution control (APC) residues from municipal solid waste (MSW) incinerators are typically

\footnotetext{
* Corresponding author. Tel.: +86 21 65986104; fax: +86 21 65986104 .

E-mail addresses: solidwaste@mail.tongji.edu.cn, xhpjk@mail.tongji.edu.cn (P.-J. He).
}

classified as hazardous waste because they contain large amounts of leachable heavy metals, soluble salts and trace organic pollutants, which must be disposed of with care (Reijnders, 2005). He et al. (2005) reported for the first time the characteristics and pollution potentials of APC residues generated in an incinerator in Shanghai. When the APC residues were wet and exposed to air, aging (or natural weathering) occurred. Carbonation is regarded as the main 
mechanism of the aging-induced reduction of the solubility of metals, owing to the low solubility of heavy metal carbonates. Accordingly, aging has been proposed to be a means of immobilizing residues that are contaminated with heavy metals (Macias et al., 1997; Walton et al., 1997; Bin-Shafique et al., 1998; Valls and Vàzquez, 2001; Venhuis and Reardon, 2001; Ecke et al., 2002).

Aging is a complex process of numerous interrelated chemical reactions, including carbonation, hydrolysis, hydration, dissolution/precipitation, complexation with organic and inorganic ligands, surface complexation, surface precipitation, sorption, formation of solid solutions and oxidation/reduction (Sabbas et al., 2003). Table 1 lists the literature examines the effect of APC residues aging on metal immobilization. The partial pressure of $\mathrm{CO}_{2}$ and the reaction time were proposed more important parameters than the amount of water added or the temperature of fly ash carbonation (Ecke et al., 2003). Water is a critical ingredient in carbonation, but an excess of water suppresses $\mathrm{CO}_{2}$ diffusion into the suspension (Fernández Bertos et al., 2004). By establishing that carbonation is much faster under dynamic conditions than under static conditions, Fernández Bertos et al. (2004) established that the diffusion of $\mathrm{CO}_{2}$ into ash particles is the rate-controlling step. The optimal liquid to solid ratio $(L / S)$ was $0.2-0.3$ for APC residues, using pure $\mathrm{CO}_{2}$ at pressure of three bars.

If the transfer rate of $\mathrm{CO}_{2}$ were the rate-controlling step of the aging of APC residues, then the way in which water is added and distributed within samples should significantly affect the rate of carbonation. Table 1 demonstrates that the $L / S$ ratios considered in the literature are under 0.6 , and claims are made of the effect of $\mathrm{CO}_{2}$ on aging without experimental support. In this work, APC residues with $L / S=0.25$ and 10 were aged with or without exposure to ambient air. This study shows that the distribution of the added water considerably influences the aging process, via mechanisms that are discussed in certain detail.

\section{Materials and Methods}

The APC residues employed in this study were sampled from the Yuqiao MSW Incineration Plant (mass burn) in Shanghai, which treats approximately 1000 tons of MSW daily. The plant removes acid gas from the flue gas stream using lime slurry $(10 \% \mathrm{w} / \mathrm{w})$; heavy metals and dioxins using activated carbon (50 $\mathrm{mg} \mathrm{m}^{-3}$ ), and particulates using bag filters. The APC residues were collected from the semidry reactors and the fabric filters, containing particles from the incineration chamber, reaction products and some excess reactants, primarily $\mathrm{Ca}(\mathrm{OH})_{2}$. The raw residues had a low water content of $0.37 \% \mathrm{w} / \mathrm{w}$.

Fernández Bertos et al. (2004) posited that the optimal $L / S$ is $0.2-0.3$ for APC residues. Accordingly, in this study, raw ash was mixed with distilled water to a moisture content of $20 \% \mathrm{w} / \mathrm{w}(L / S=0.25$ $\mathrm{w} / \mathrm{w})$ to form a sample with a low to moderate moisture content. Then, some of the wet ash was sealed in a $500 \mathrm{ml} \mathrm{PE}$ bottle that contained no air; the rest of the sample was spread in enamel trays to a thickness of 20 $\mathrm{mm}$ and exposed to ambient air. Mineralogical analyses of both samples using a D/max $2550 \mathrm{X}$-ray diffractometer (XRD, Rigaku Corporation, Japan), were conducted before and after 30-day test. Comparing the data for the sealed and the spread samples elucidated the possible effect of exposure to $\mathrm{CO}_{2}$ on ash characteristics.

In each of the sixteen cylindrical chambers, $100 \mathrm{~g}$ raw ash was thoroughly mixed with 11 distilled water $(L / S=10 \mathrm{w} / \mathrm{w})$ and then kept still with its upper surface exposed to air, to determine whether the dif-

Table 1

Literature works considering ash aging process

\begin{tabular}{lllll}
\hline Works & $L / S(\mathrm{w} / \mathrm{w})$ & $\mathrm{CO}_{2}$ & Metals studied & Remarks \\
\hline Ecke et al. (2003) & $0,0.5$ & $0.03 \%$ and $50 \% \mathrm{v} / \mathrm{v}$ & $\mathrm{Pb}, \mathrm{Zn}, \mathrm{Cd}, \mathrm{Cr}$ & Flow chamber \\
Shimaoka et al. (2002) & $0-0.6$ & $0-30 \% \mathrm{v} / \mathrm{v}$ & $\mathrm{Pb}$ & Flow chamber \\
Kim et al. (2003) & $0.05-0.2$ & $10 \% \mathrm{v} / \mathrm{v}$ & $\mathrm{Pb}, \mathrm{Ca}, \mathrm{Cd}$ & Aged with bottom ash \\
Fernández Bertos et al. (2004) & $0-0.6($ opt. $0.2-0.3)$ & $\mathrm{Pure} \mathrm{CO}_{2}(3$ bars) $)$ & $\mathrm{Pb}, \mathrm{Zn}$ & Shaken or still chambers \\
This work & $0.25,10$ & $0.03 \% \mathrm{v} / \mathrm{v}$ & $\mathrm{Ca}, \mathrm{Cd}, \mathrm{Cr}, \mathrm{Cu}, \mathrm{Ni}, \mathrm{Pb}, \mathrm{Zn}, \mathrm{As}, \mathrm{Hg}$ Still chamber \\
\hline
\end{tabular}


fusional resistance of $\mathrm{CO}_{2}$ limits the rate of carbonation with a large amount of water. The amount $L /$ $S=10$ was adopted since it is also the recommended ratio in numerous leaching standard tests, including EN 12457 (EU), EPTSW (China), JLT 13 (Japan), and DIN38414 S4 (Germany). The ash quickly settled to a bottom layer with a thickness of $20 \mathrm{~mm} . \mathrm{CO}_{2}$ could be supplied only from the top surface of the water. Such a test involves a sample with a high moisture content. In the sixteen chambers that contained APC residues at $L / S=10$, a thin layer of precipitate would rapidly form on the top surface of the water. In eight chambers, this thin layer was not touched during the test. In the other eight chambers, this layer was carefully removed after it had formed. Ecke et al. (2002) revealed the rather high solubility $(>5-10 \%)$ of fly ash at $L / S=10$ and $25^{\circ} \mathrm{C}$. Suspension samples were extracted from the supernatant layer at $0,8,24,48,96$, 144,360 and $720 \mathrm{~h}$, and were filtered using a $0.45 \mu \mathrm{m}$ membrane before their $\mathrm{pH}$ and metal concentrations were measured. An AA-6501F FAAS (Shimadzu Corporation, Japan) was used to analyze the levels of $\mathrm{Ca}$, $\mathrm{Cd}, \mathrm{Cr}, \mathrm{Cu}, \mathrm{Ni}, \mathrm{Pb}$ and $\mathrm{Zn}$, and a XGY1012 AFS (atomic fluorescence spectrometer, Institute of Geophysical and Geochemical Exploration of the Chinese Academy of Sciences, China) was used to measure the concentrations of $\mathrm{As}$ and $\mathrm{Hg}$. The variability of $\mathrm{pH}$ measurement was within 0.08 , and heavy metals concentration within $2 \%$. The cross-sectional compositions of the heavy metals on the particle surface were scanned using a scanning electron microscope (Philips XL30) equipped with an energy dispersive Xray spectrometer (EDAX DX4).

\section{Results and discussion}

\subsection{APC characteristics}

Table 2 lists the leaching characteristics of the APC residues through the Extraction Procedure for Toxicity of Solid Waste (EPTSW). Independent tests revealed that the surface area of this ash sample was about $5 \mathrm{~m}^{2} \mathrm{~g}^{-1}$, so the material was not very porous. Notably, the leachate $\mathrm{pH}$ of ash, and the concentrations of $\mathrm{Hg}$ and $\mathrm{Pb}$ in leachate all violate the current national standards of China, so the material is classified as hazardous. Additionally, the calcium concentration in the leachate is high, at approximately $3000 \mathrm{mg} 1^{-1}$, indicating that the carbonic acid is easily precipitated.

\subsection{Effects of carbonation on mineralogy of $A P C$ residues $(L / S=0.25)$}

Comparing the XRD spectra of the raw ash sample and the carbonated ash $(L / S=0.25)$, the latter contained calcite and gypsum (Fig. 1). No calcite appeared in the sealed sample without air available, and the gypsum content was not substantially increased. Rather, ettringite $\left[\mathrm{Ca}_{6} \mathrm{Al}_{2}\left(\mathrm{SO}_{4}\right)_{3}(\mathrm{OH})_{12}\right.$. $26 \mathrm{H}_{2} \mathrm{O}$ ] had formed in the wet and sealed residues. Shimaoka et al. (2002) also observed similar compounds in their scrubber residues, and found that aging almost completely eliminated them. Accordingly, $\mathrm{CaSO}_{4}$ and $(\mathrm{Na}, \mathrm{K}) \mathrm{Al}_{3}\left(\mathrm{SO}_{4}\right)_{2}(\mathrm{OH})_{6}$ in raw ash might react initially with water to produce ettringite, which was transformed to more stable forms of sul-

Table 2

Leaching characteristics of the APC residues samples based on Extraction Procedure for Toxicity of Solid Waste (GB5086.1-1997, 1997)

\begin{tabular}{|c|c|c|c|c|c|c|c|c|c|}
\hline Item & $\mathrm{pH}$ & $\mathrm{As} /\left(\mathrm{mg} \mathrm{l}^{-1}\right)$ & $\mathrm{Cd} /\left(\mathrm{mg} \mathrm{l}^{-1}\right)$ & $\mathrm{Cr} /\left(\mathrm{mg}^{-1}\right)$ & $\mathrm{Cu} /\left(\mathrm{mg} \mathrm{l}^{-1}\right)$ & $\mathrm{Hg} /\left(\mathrm{mg} \mathrm{l}^{-1}\right)$ & $\mathrm{Ni} /\left(\mathrm{mg} \mathrm{1^{-1 }}\right)$ & $\mathrm{Pb} /\left(\mathrm{mg} \mathrm{l}^{-1}\right)$ & $\mathrm{Zn} /\left(\mathrm{mg} \mathrm{1}^{-1}\right)$ \\
\hline This study* & 13.0 & 0.001 & 0.04 & 0.36 & 0.13 & 0.164 & 0.18 & 63.6 & 2.26 \\
\hline Average** & $12.6(0.3)$ & $0.001(0.001)$ & $0.12(0.07)$ & $0.23(0.17)$ & $0.25(0.17)$ & $0.14(0.16)$ & $0.38(0.20)$ & $88(40)$ & $4(2)$ \\
\hline Limited value $* * *$ & 12.5 & 1.5 & 0.3 & 10 & 50 & 0.05 & 10 & 3 & 50 \\
\hline Item & \multicolumn{3}{|c|}{ Electric conductivity/(ms cm $\left.{ }^{-1}\right)$} & \multicolumn{3}{|c|}{$\mathrm{Cl}^{-} /\left(\mathrm{mg} \mathrm{l}^{-1}\right)$} & \multicolumn{2}{|l|}{$\mathrm{SO}_{4}^{2-} /\left(\mathrm{mg}^{-1}\right)$} & $\mathrm{Ca} /\left(\mathrm{mg} \mathrm{l}^{-1}\right)$ \\
\hline This study* & \multirow{2}{*}{\multicolumn{2}{|c|}{27.1}} & & \multicolumn{3}{|c|}{8600} & \multicolumn{2}{|l|}{1900} & 2950 \\
\hline Average** & & \multicolumn{2}{|c|}{$31.6(3.4)$} & \multicolumn{3}{|c|}{$10,000(3190)$} & $1300(600)$ & & $3410(670)$ \\
\hline
\end{tabular}

* Referring to the leaching characteristics of the APC residues used in this study.

** The data cover leaching tests for ten APC residues sampled from the Yuqiao MSW Incineration Plant at different seasons in 2 years (He et al., 2004). The values in the bracket mean standard deviation.

*** According to the national standard of China to be classified as hazardous materials (GB5085.1-1996, GB5085.3-1996, 1996). 


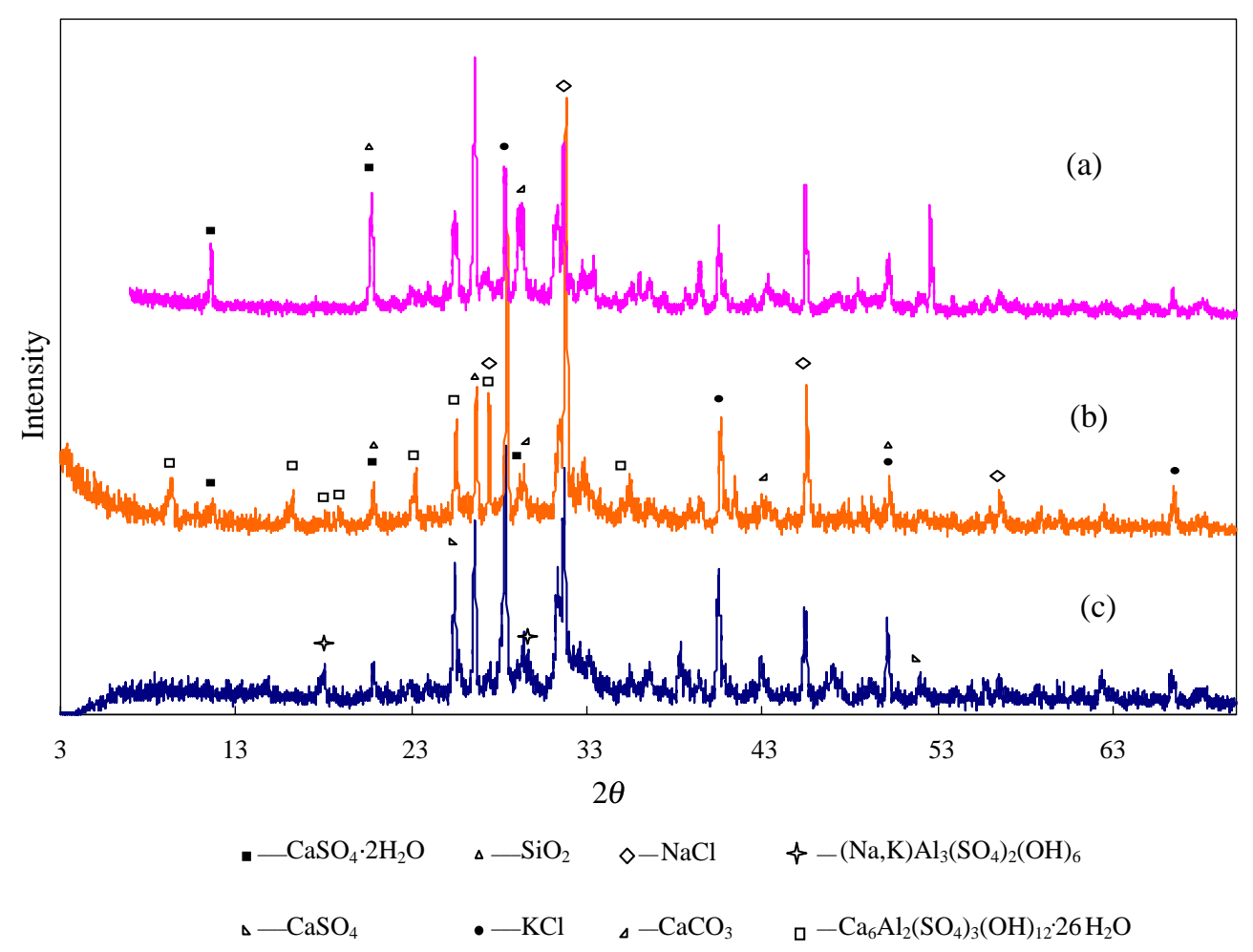

Fig. 1. The XRD spectra of the APC residues. (a) aged sample, (b) wet and sealed sample, (c) raw sample.

fate, carbonate and hydroxide, gypsum, calcite and possibly gibbsite, when $\mathrm{CO}_{2}$ was present.

Fig. 2 displays typical SEM/EDS images of the raw and aged samples. The elemental compositions of the sample surfaces were estimated by averaging more than 40 images taken of the samples at random. The contents of the main elements in the raw residues followed the sequence $\mathrm{O}>\mathrm{C}, \mathrm{Ca}, \mathrm{Si}, \mathrm{Cl}>\mathrm{K}, \mathrm{Na}, \mathrm{Al}$, $\mathrm{S}$ (Fig. 3). In the aged residues, the abundance of $\mathrm{C}$ and $\mathrm{O}$ increased significantly from $12.4 \%$ to $24.9 \%$, and from $33.1 \%$ to $47.0 \%$, respectively, supporting to the conclusion that carbonation occurred in the ash samples by natural aging.

\subsection{Aging of $A P C$ residues $(L / S=10)$}

The SEM micrographs reveal that the layer of precipitate noted in the $L / S=10$ tests contains much calcite (Fig. 4(a)) with scattered spots of gypsum (Fig. 4(b)). Most of the precipitate was fine crystals of calcite that were smaller than $5 \mu \mathrm{m}$, packed closely into a compact skin layer on the surface of the water. This occurrence was unsurprising because the concentration of calcium ions was approximately $3000 \mathrm{mg}^{-1}$ and the top water surface represented the only route along which $\mathrm{CO}_{2}$ could enter. Fig. 5 presents the $\mathrm{pH}$ evolutions of the suspension of APC residues $(L / S=10)$ with and without the surface precipitate layer. Initially, the fly ash suspension was at $\mathrm{pH}$ 12.4. During the $720 \mathrm{~h}$ test, the $\mathrm{pH}$ of the suspension with the precipitate layer remained almost unchanged. In extended tests, the $\mathrm{pH}$ of the suspension remained above 12 for a month (data not shown). In the test with precipitate layer removed, the $\mathrm{pH}$ fell slowly from 12.4 to about 10.6 over 50 to $360 \mathrm{~h}$. Some earlier studies also established that the $\mathrm{pH}$ of the fly ash suspension declined to around 10 (Hjelmar and Birch, 1997; Shimaoka et al., 2002; Bone et al., 2003; Ecke et al., 2003). After about 8 h, three distinct behaviors were observed. The concentrations of $\mathrm{Pb}, \mathrm{Zn}, \mathrm{Cd}, \mathrm{Hg}$ and $\mathrm{Cu}$ began to fall 
(a)

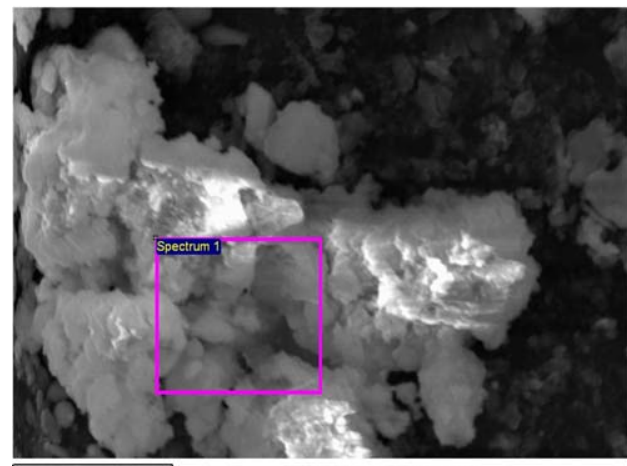

$10 \mu \mathrm{m} \quad$ Electron Image 1

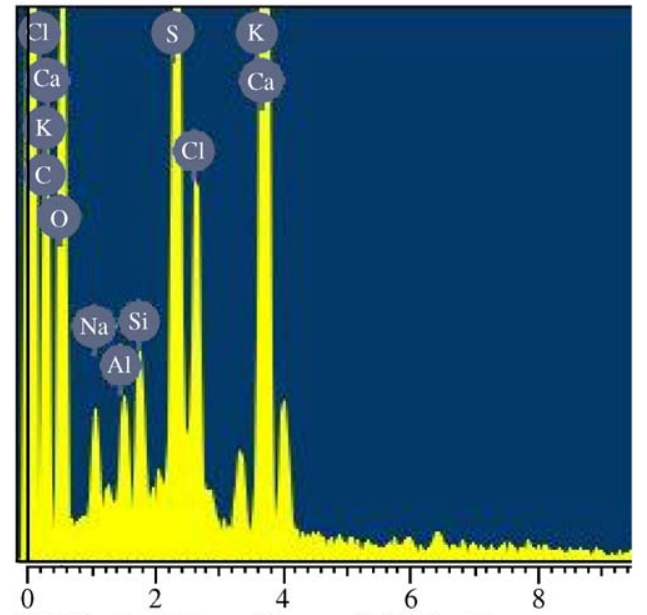

Full Scale 304 cts Cursor: $0.000 \mathrm{keV}$ (b)

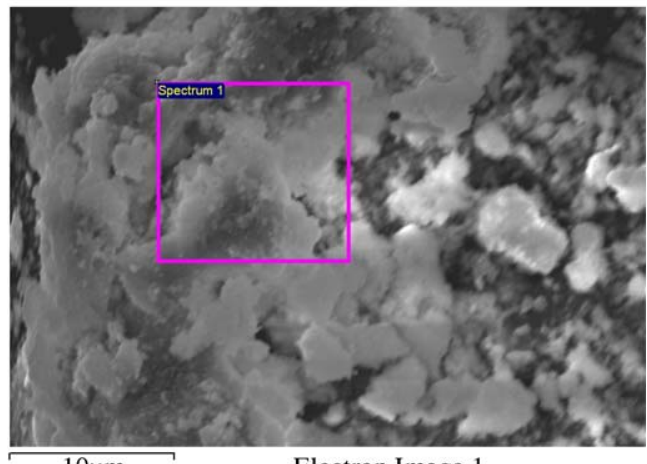

$10 \mu \mathrm{m} \quad$ Electron Image 1

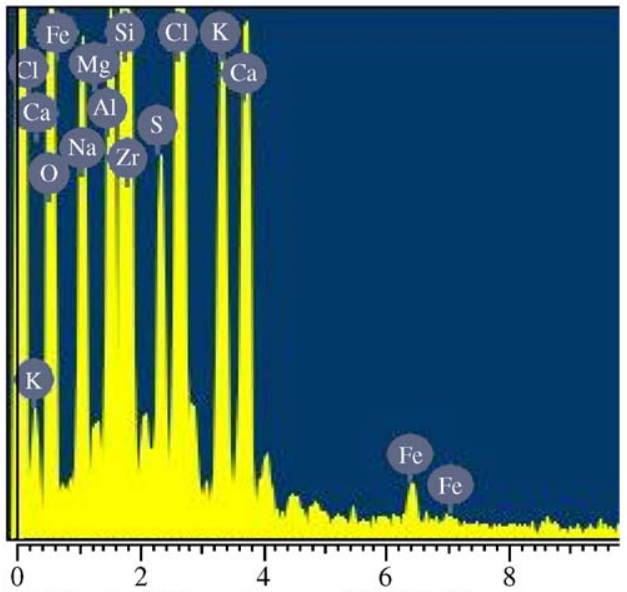

Full Scale 304 cts Cursor: $0.000 \mathrm{keV}$

Fig. 2. The SEM/EDS spectra of APC residues samples. (a) raw residues, (b) aged residues.

(Fig. 6(a)-(e)). Those of $\mathrm{Ca}$ and $\mathrm{Ni}$ remained unchanged (Fig. 6(f)-(g)), and that of $\mathrm{Cr}$ increased (Fig. 6(h)).

When many metal ions are present in a solution, the one that must bond with the least $\mathrm{CO}_{3}^{2-}$ to form the carbonate precipitate settles first. The reaction equilibrium between the divalent metal ion and the carbonate ion is:

$$
\mathrm{M}^{2+}+\mathrm{CO}_{3}^{2-} \leftrightarrow \mathrm{MCO}_{3} \downarrow
$$

The minimum concentration of $\mathrm{CO}_{3}^{2-}$ required to form $\mathrm{MCO}_{3}$ precipitate at a given metal ion concentration is $\left[\mathrm{CO}_{3}^{2-}\right]_{0}=\frac{K_{\mathrm{sp}}}{M^{2+}}$. Table 3 presents the calculated $\left[\mathrm{CO}_{3}^{2-}\right]_{0}$ with the metal ion concentrations in the initial ash suspension $(L / S=10)$.
The data in Table 3 demonstrate that when $\mathrm{CO}_{2}$ was dissolved and transferred from the top water surface, the order of precipitation was $\mathrm{Pb}^{2+}, \mathrm{Ca}^{2+}$, $\mathrm{Zn}^{2+},\left(\mathrm{Cu}^{2+}, \mathrm{Hg}^{+}\right), \mathrm{Cd}^{2+}$. With the exception of $\mathrm{Ca}^{2+}$, which was abundant in the fly ash and was supplied by continuous dissolution with aging (shown later), the concentrations of the other five metal ions decreased with aging (Fig. 6(a)-(e)). The very high concentration of $\mathrm{Ca}^{2+}$ easily precipitated when $\mathrm{CO}_{3}^{2-}$ was available, promoting the formation of the noted surface precipitate layer in the test.

The $\mathrm{CO}_{3}^{2-}$ concentration was as high as around $0.03 \mathrm{~mol}^{-1}$ to precipitate $\mathrm{Ni}^{2+}$, which was not achievable in the test herein. This observation reveals why the $\mathrm{Ni}^{2+}$ concentration remained unchanged throughout the test. 
(a)

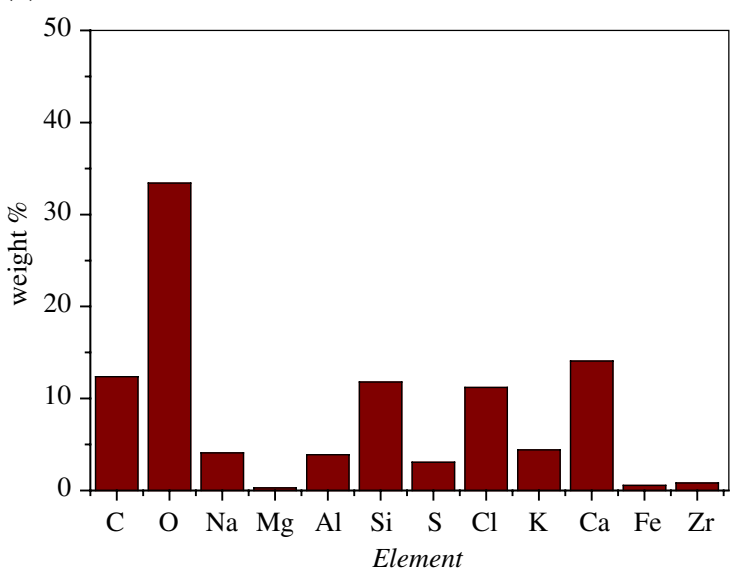

(b)

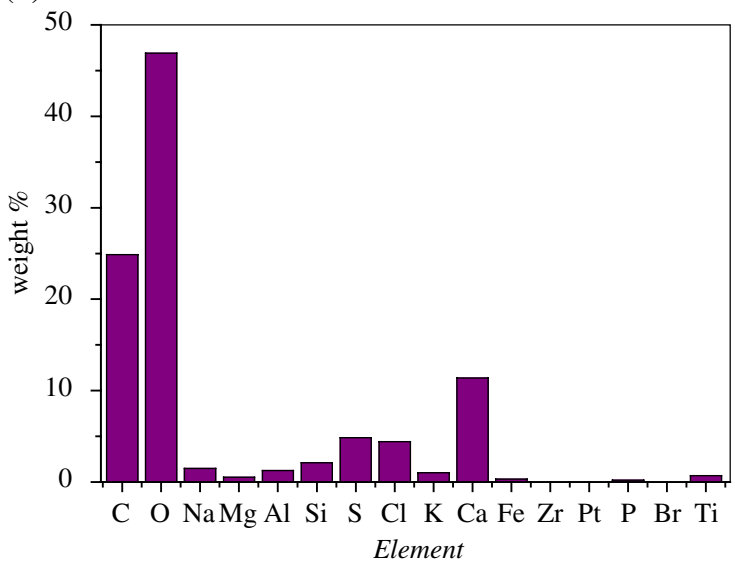

Fig. 3. Mean weight percents of main elements of APC residues samples. (a) raw residues, (b) aged residues.

Unlike for the other metals examined, the concentration of $\mathrm{Cr}$ increased with aging, probably because $\mathrm{Cr}^{3+}$ was oxidized by dissolved oxygen to the more soluble form, $\mathrm{Cr}^{6+}$ (Ecke et al., 2003).

The decline in the concentrations of $\mathrm{Pb}, \mathrm{Zn}, \mathrm{Cd}$ and $\mathrm{Hg}$, but not $\mathrm{Cu}$, was faster in the test without a surface precipitate layer than in the test with a surface layer. This observation is attributable to the provision of a mass transfer barrier by the compact surface layer, through which $\mathrm{CO}_{2}$ had to pass. For example, the drop in the concentration of $\mathrm{Pb}$ from 105 to $25 \mathrm{mg} \mathrm{l}^{-1}$ took $150 \mathrm{~h}$ in the test without a surface precipitate layer. When the surface layer was present, the time required exceeded $720 \mathrm{~h}$. The corresponding times required for the drop in the concentration of $\mathrm{Zn}$ from $15-20 \mathrm{mg}$ $\mathrm{1}^{-1}$ to around $3 \mathrm{mg} \mathrm{l}^{-1}$ were 100 and $400 \mathrm{~h}$, respectively. Accordingly, when APC residues were mixed with water, the rate of carbonation varied greatly with the manner in which the precipitate was formed and where it was precipitated. When a compact precipitate was formed on the pathway of the $\mathrm{CO}_{2}$, although the chemical equilibrium calculation revealed the same results, the corresponding carbonation reaction was substantially slower.

Fig. 6(h) unsurprisingly reveals that more $\mathrm{Cr}$ was present in soluble form in the test without a precipitate surface layer than in the test with a surface layer, because the compact surface layer also slowed the dissolution of oxygen into water. However, the increase in the dissolution of $\mathrm{Cr}$ became marked only after $100-150 \mathrm{~h}$ of testing. An optimal period of aging should be used to immobilize heavy metal. In this particular test, the optimal time was $100 \mathrm{~h}$, without the release of $\mathrm{Cr}$, which detrimentally affects the management of residues.

\subsection{Rate-controlling step}

Insights into carbonation can be gained by comparing the incorporated mass transfer rate with the chemical reaction rate. For the system adopted for $L / S=10, \mathrm{CO}_{2}$ dissolves at the top water surface, according to Henry's Law:

$$
\begin{gathered}
\mathrm{CO}_{2} \text { mol fraction }\left(x_{0}\right)=\frac{p_{e}}{E}=\frac{30}{1.66 \times 10^{8}} \\
=1.8 \times 10^{-7} \quad\left(\mathrm{~mol} \mathrm{~mol}^{-1}\right)
\end{gathered}
$$

where,

$p_{\mathrm{e}} \quad \mathrm{CO}_{2}$ partial pressure, $30 \mathrm{~Pa}$ in air;

$E$ Henry coefficient, $\mathrm{Pa}$, for $\mathrm{CO}_{2}$ in water, which is $1.66 \times 10^{8} \mathrm{~Pa}$ at $25^{\circ} \mathrm{C}$.

If, as posited by Fernández Bertos et al. (2004), the diffusion of $\mathrm{CO}_{2}$ into ash particles is the rate-controlling step in ash carbonation, then an order-of-magnitude estimate of the rate at which dissolved $\mathrm{CO}_{2}$ is transferred from the top surface to the bottom layer of residues is as follows:

$N_{\mathrm{A}, \mathrm{CO}_{2}}=D \cdot \frac{x_{0}}{L}$ 


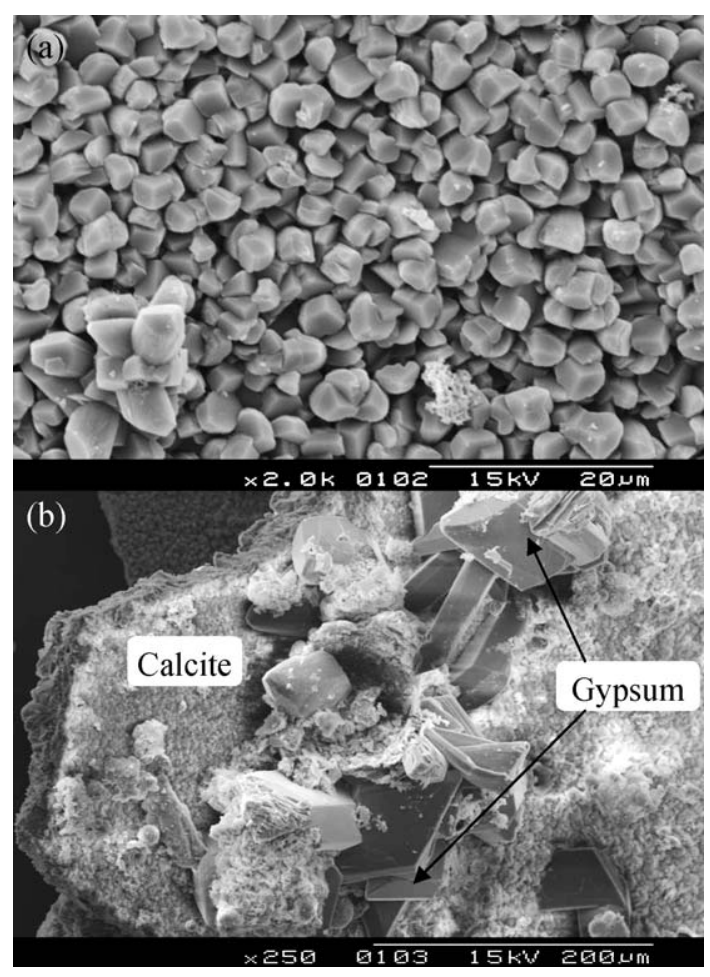

Fig. 4. The SEM micrographs of the surface precipitate layer with the magnification of (a) $2000 \times$ and (b) $250 \times$.

where,

$N_{\mathrm{A}, \mathrm{CO}_{2}}$ Rate of diffusion of dissolved $\mathrm{CO}_{2}$ from the top surface to the bottom layer of residues;

$L \quad$ thickness of water above the ash layer, 0.08 $\mathrm{m}$ herein;

$D$ diffusion coefficient of $\mathrm{CO}_{2}$ in water at 25 ${ }^{\circ} \mathrm{C}, 1.96 \times 10^{-9} \mathrm{~m}^{2} \mathrm{~s}^{-1}$.
The $\mathrm{CO}_{2}$ concentration on top surface of the water $\left(x_{0}\right)=1.8 \times 10^{-7} \times 5.56 \times 10^{4}=1 \times 10^{-2} \mathrm{~mol} \mathrm{m^{-3 }}$. Accordingly, the rate of $\mathrm{CO}_{2}$ diffusion is approximated as $N_{\mathrm{A}, \mathrm{CO}_{2}}=1.96 \times 10^{-9} \frac{\mathrm{m}^{2}}{\mathrm{~s}} \times \frac{0.01 \mathrm{molm}^{-3}}{0.08 \mathrm{~m}}=2.45 \times$ $10^{-10} \mathrm{~mol}\left(\mathrm{~m}^{2} \mathrm{~s}\right)^{-1}$. The cross-sectional area of the top water surface is $(\pi / 4) \times(0.12 \mathrm{~m})^{2}=0.0113 \mathrm{~m}^{2}$, yielding a diffusional flow of $9.97 \times 10^{-9} \mathrm{~mol} \mathrm{~h}^{-1}$. If, however, all $\mathrm{CO}_{2}$ is assumed to convert to $\mathrm{CO}_{3}^{2-}$ after it is dissolved in water, given that the diffusion coefficient of the latter in water is only $0.92 \times 10^{-9}$ $\mathrm{m}^{2} \mathrm{~s}^{-1}$, the corresponding diffusional flow would be even lower. Hence, the above estimate is an upper limit on the diffusional flow of carbonate ions.

Consider the consumption of $\mathrm{Pb}^{2+}$ as an example of the calculation. The lead concentration fell from $104 \mathrm{mg}^{-1}$ to almost zero over $100-700 \mathrm{~h}$ (Fig. 6(a)). The minimum quantity of $\mathrm{Pb}^{2+}$ consumed in the chamber was estimated as $\left(11 \times 104 \mathrm{mg} \mathrm{l}^{-1}\right.$ / $\left.\left(207 \mathrm{~g} \mathrm{~mol}^{-1}\right)=\right) 5 \times 10^{-4} \mathrm{~mol}$. Therefore, the time taken for $\mathrm{CO}_{2}$ to transfer from top surface to bottom residues layer to precipitate all lead is around $\left(5 \times 10^{-4} \mathrm{~mol} / 9.97 \times 10^{-9} \mathrm{~mol} \mathrm{~h}^{-1}=\right) 50,000 \mathrm{~h}$, two to three orders of magnitudes above the experimental values (order of $\left(10^{2} \mathrm{~h}\right)$ ). Accounting for this huge time span difference could be difficult, even when the effects of enhanced gas adsorption on the alkaline solution or those of transient mass transfer caused by local depletion of carbonate ions are considered. Accordingly, the chemical reaction could proceed effectively in the ash particles that settled in the bottom layer. Rather, the chemical reaction preferentially proceeds in the bulk solution, beginning after the $\mathrm{CO}_{2}$ has dissolved and hydrolyzed at the top surface of the water. The dissolution and diffusion of $\mathrm{CO}_{2}$ in the bulk solution is the rate-

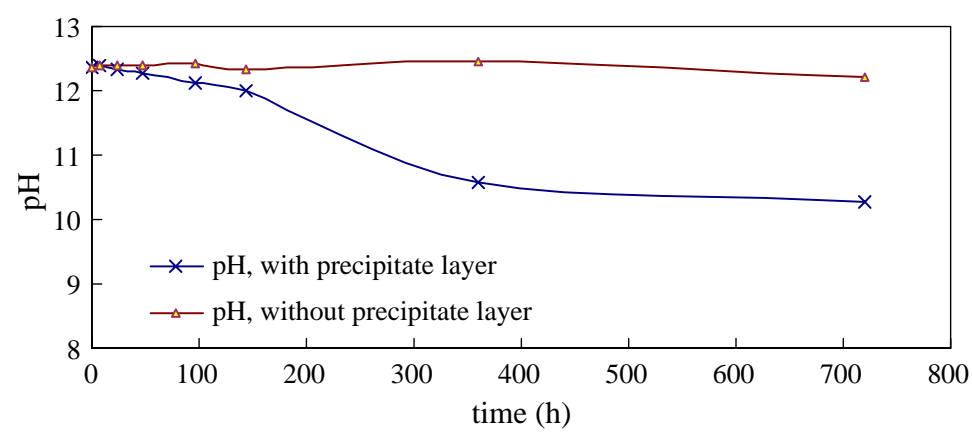

Fig. 5. pH evolutions of suspensions of fly ashes with or without surface precipitate layer. 
limiting step of the carbonation of ash suspension $(L / S=10)$.

Most heavy metal ions in water have a diffusion coefficient of the order of $10^{-9} \mathrm{~m}^{2} \mathrm{~s}^{-1}$. For example,
$\mathrm{Ca}^{2+}$ has a diffusion coefficient of $0.79 \times 10^{-9} \mathrm{~m}^{2} \mathrm{~s}^{-1}$ in water at $25{ }^{\circ} \mathrm{C}$. If calcium ions were released from the bottom ash layer to form a highly saturated solution with an ion concentration of $10 \mathrm{~mol} \mathrm{~m}^{-3}$, then the

(a)

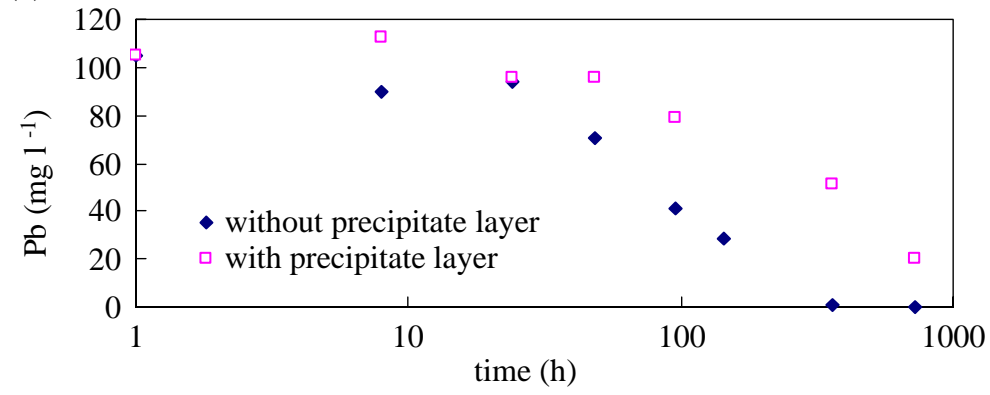

(b)

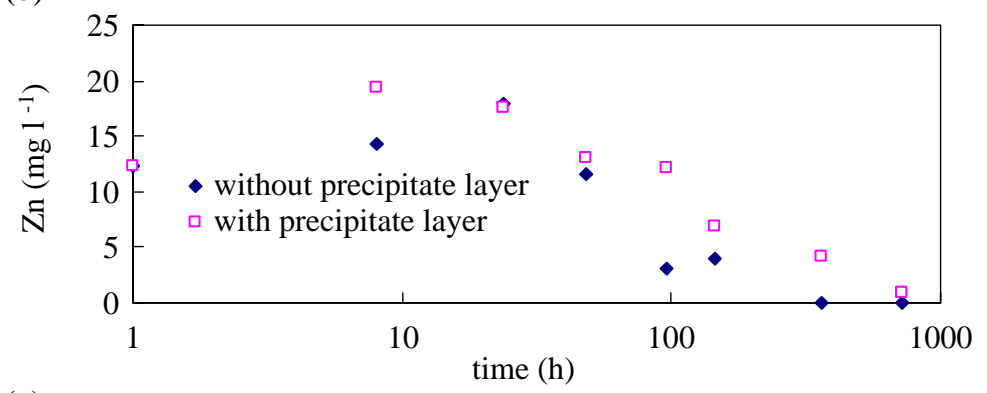

(c)

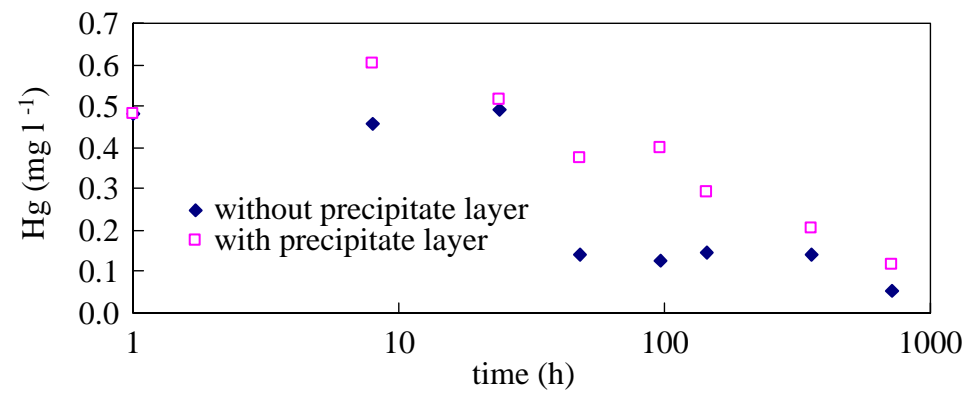

(d)

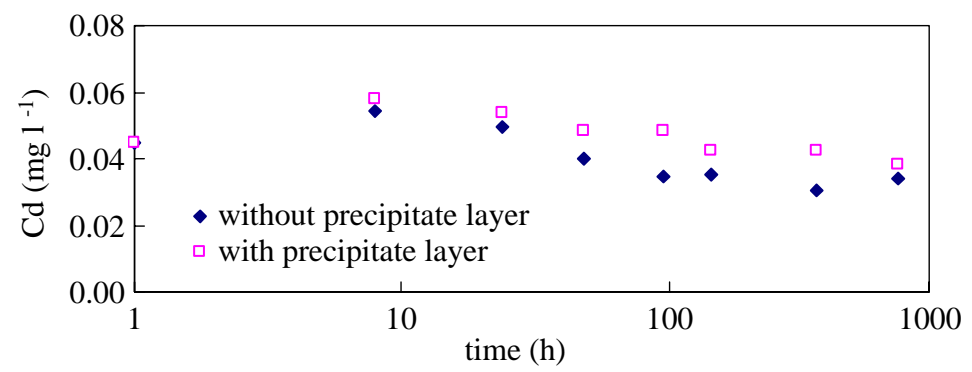

Fig. 6. Concentrations of heavy metals in supernatant with or without surface precipitate layers. (a) $\mathrm{Pb}$, (b) $\mathrm{Zn}$, (c) $\mathrm{Hg}$, (d) $\mathrm{Cd}$, (e) $\mathrm{Cu}$, (f) $\mathrm{Ca}$, (g) $\mathrm{Ni}$, (h) Cr. 
(e)

(f)
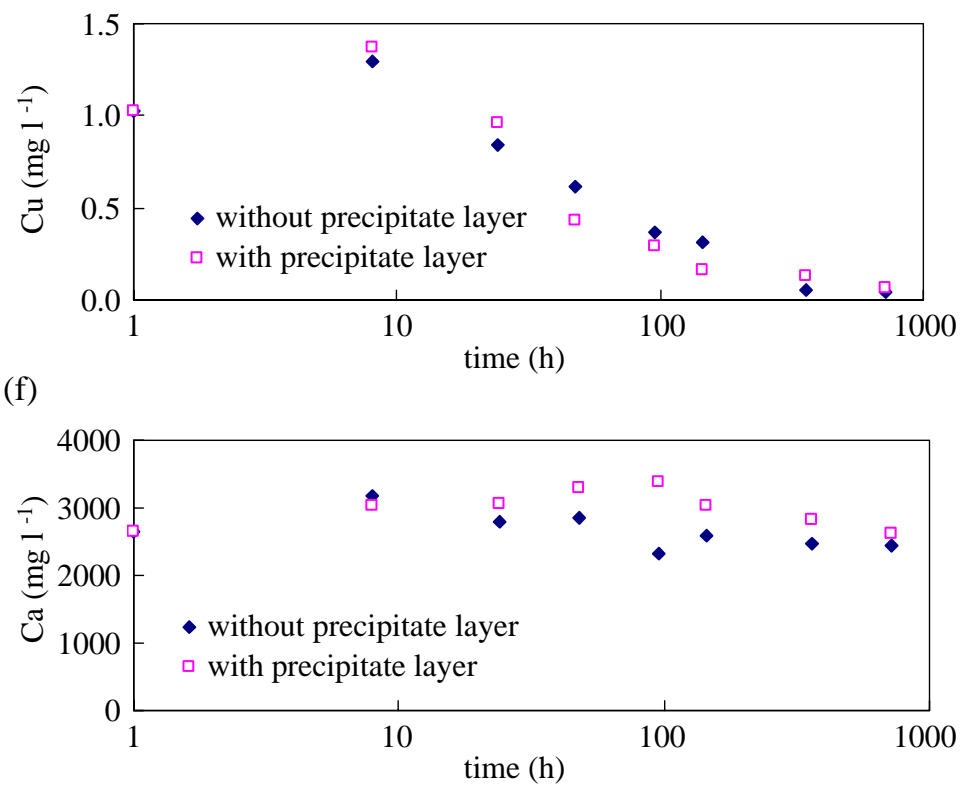

(g)

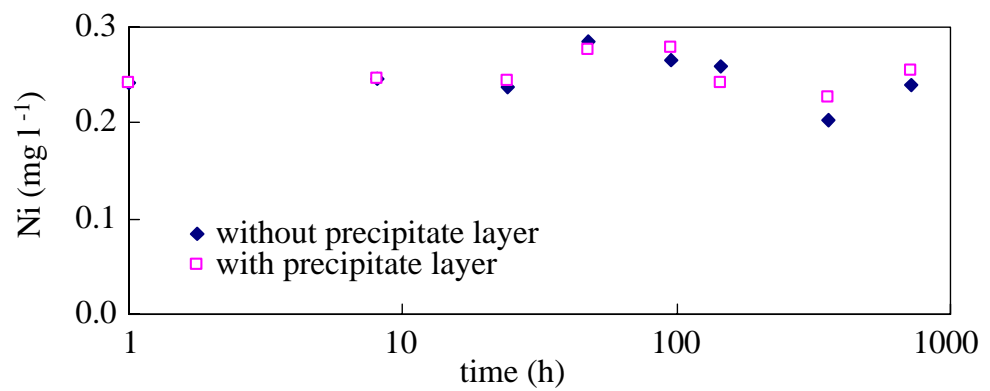

(h)

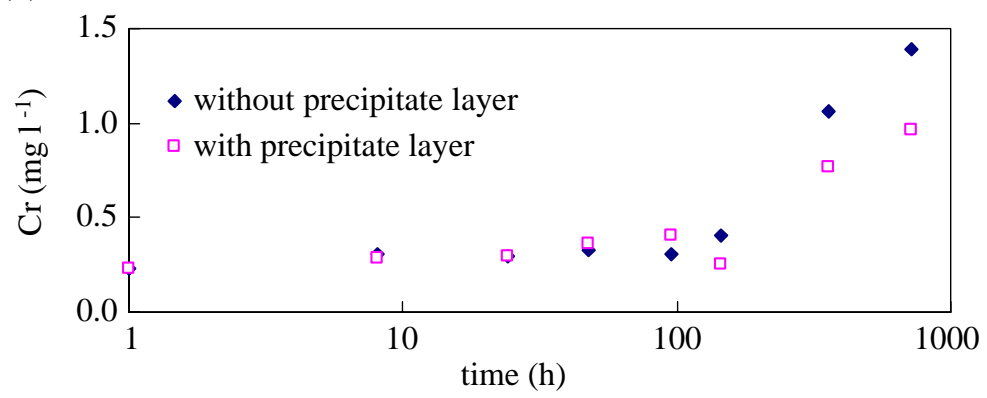

Fig. 6 (continued).

corresponding diffusional flux from the bottom to top surface is estimated as follows; $N_{\mathrm{Ca}^{2+}}=0.79 \times$ $10^{-9} \frac{\mathrm{m}^{2}}{\mathrm{~s}} \times \frac{10 \mathrm{~mol} \mathrm{~m}^{-3}}{0.08 \mathrm{~m}} \times 0.0113 \mathrm{~m}^{2}=4.02 \times 10^{-6} \mathrm{~mol}$ $\mathrm{h}^{-1}$. This value greatly exceeds that of the corresponding $\mathrm{CO}_{2}$ flow $\left(9.97 \times 10^{-9} \mathrm{~mol} \mathrm{~h}^{-1}\right)$, yielding an almost constant $\mathrm{Ca}$ concentration throughout the aging test, as presented in Fig. 6(f). Meanwhile, the decrease in metal concentrations displayed 
Table 3

Precipitation analysis of metal carbonate

\begin{tabular}{|c|c|c|c|}
\hline Compounds & $\begin{array}{l}K_{\text {sp }}\left(25^{\circ} \mathrm{C}\right) \\
\text { (Cai et al., 1998; } \\
\text { Zheng and Zhu, } \\
\text { 1999) }\end{array}$ & {$\left[\mathrm{M}^{2+}\right] /\left(\mathrm{mol} \mathrm{l}^{-1}\right)$} & {$\left[\mathrm{CO}_{3}^{2-}\right]_{0} /\left(\mathrm{mol} \mathrm{l}^{-1}\right)$} \\
\hline $\mathrm{PbCO}_{3}$ & $1.46 \times 10^{-13}$ & $5.07 \times 10^{-4}$ & $2.88 \times 10^{-10}$ \\
\hline $\mathrm{CaCO}_{3}$ & $4.96 \times 10^{-9}$ & $6.64 \times 10^{-2}$ & $7.47 \times 10^{-8}$ \\
\hline $\mathrm{ZnCO}_{3}$ & $1.19 \times 10^{-10}$ & $1.89 \times 10^{-4}$ & $6.30 \times 10^{-7}$ \\
\hline $\mathrm{CuCO}_{3}$ & $1.4 \times 10^{-10}$ & $1.62 \times 10^{-5}$ & $8.65 \times 10^{-6}$ \\
\hline $\mathrm{Hg}_{2} \mathrm{CO}_{3} *$ & $3.67 \times 10^{-17}$ & $2.40 \times 10^{-6}$ & $6.40 \times 10^{-6}$ \\
\hline $\mathrm{CdCO}_{3}$ & $6.18 \times 10^{-12}$ & $3.99 \times 10^{-7}$ & $1.55 \times 10^{-5}$ \\
\hline $\mathrm{NiCO}_{3}$ & $1.42 \times 10^{-7}$ & $4.11 \times 10^{-6}$ & $3.46 \times 10^{-2}$ \\
\hline
\end{tabular}

*For monovalent metal ion, $\left[\mathrm{CO}_{3}^{2-}\right]_{0}=\frac{K_{\mathrm{sp}}}{\left[M^{+}\right]^{2}}$.

in Fig. 6(a)-(e) during aging revealed that most dissolvable $\mathrm{Pb}, \mathrm{Zn}, \mathrm{Cd}, \mathrm{Cu}$ and $\mathrm{Hg}$ were released to the bulk suspension and completely consumed by carbonation in 150-700 h.

Therefore, given a water thickness of $8 \mathrm{~cm}$, the rate-controlling step of aging was the dissolution of $\mathrm{CO}_{2}$ (or $\mathrm{CO}_{3}^{2-}$ ) at the top water surface and its transport through and reaction in the bulk solution. The particle size or the surface area of the ash particles does not affect natural aging when the moisture content is high. Meanwhile, agitation should be able to promote the transfer rate of $\mathrm{CO}_{3}^{2-}$, whence its reaction rate in the bulk, as noted by Fernández Bertos et al. (2004).

In the tests with $L / S=0.25$, the $100 \mathrm{~g}$ sample was mixed with $25 \mathrm{~g}$ of water. Under extreme conditions in which all particle surfaces were coated uniformly with a liquid film, the mean thickness of the liquid film was $50 \mathrm{~nm}\left(25 \mathrm{~cm}^{3} /\left(100 \mathrm{~g} \times 5 \mathrm{~m}^{2} / \mathrm{g}\right)\right)$. Given such a thin film, the corresponding $N_{\mathrm{A}, \mathrm{CO}_{2}}$ was $1.6 \times 10^{6}$ times greater than that obtained in the $L /$ $S=10$ tests, yielding a $\mathrm{CO}_{2}$ flux of $700 \mathrm{~mol} \mathrm{~h}^{-1}$. The ambient air cannot supply as much $\mathrm{CO}_{2}$. Even at $1 \%$ of this value, the corresponding flux more than suffices to react with all metal ions in the ash samples within half an hour. Meanwhile, the dissolution of metals ions in the attached liquid film is far from complete. Accordingly, under this condition, the rate-limiting step is how fast the heavy metals could be transformed into ionic forms. Restated, the rate of dissolution of metals from ash particles controls the reaction rate. The particle size or surface area of the ash particles governs the rate of aging. Under this extreme condition, the water content is secondary, and the conclusions drawn by Ecke et al. (2003) are unsurprising: the added water is not significant in relation to the reaction time and the partial pressure of $\mathrm{CO}_{2}$.

Water content is a very important process factor, whose distribution in the sample, along with the resulting competition between the carbonate ion flux and the heavy metal flux, determines the reaction time required in this natural aging process. Accordingly, the amount of added water and the reaction time are dependent variables and should not be used as independent variables in statistical analysis to interpret experimental data.

\section{Conclusions}

This study examines the natural aging of APC residues from an MSW incinerator in Shanghai, considering in particular the effect of the amount of added water on the immobilization of the heavy metals. The liquid to solid ratio was fixed at 0.25 or 10 with or without $\mathrm{CO}_{2}$ supplied from ambient air. With a $L / S$ of 0.25 , the $\mathrm{CaSO}_{4}$ and $(\mathrm{Na}, \mathrm{K}) \mathrm{Al}_{3}\left(\mathrm{SO}_{4}\right)_{2}(\mathrm{OH})_{6}$ in the raw sample would initially react with water to yield ettringite. Then, if external $\mathrm{CO}_{2}$ were available, the ettringite would be transformed to gypsum and calcite, along with a decline in the $\mathrm{pH}$ of the suspension. The $\mathrm{C}$ and $\mathrm{O}$ contents on ash particle surface also considerably increased following natural aging at ambient air exposure.

With a sufficiently high $L / S$ (10 in this study), excess $\mathrm{Ca}^{2+}$ ions were present in the suspension, so a precipitate of mostly crystals of calcite that were smaller than $5 \mu \mathrm{m}$ form on the air-water surface. With or without this surface precipitate layer, the concentrations of $\mathrm{Pb}, \mathrm{Zn}, \mathrm{Cd}, \mathrm{Hg}$ and $\mathrm{Cu}$ fell with time, because of carbonation, following closely the precipitation sequence determined by chemical equilibrium calculations. The levels of $\mathrm{Ca}$ and $\mathrm{Ni}$ in suspensions were almost constant throughout the test, because the $\mathrm{Ca}^{2+}$ was too abundant to be completely converted and the concentration of carbonate ions required to precipitate $\mathrm{Ni}$ was too high to achieve. Additionally, the declining rates of $\mathrm{Pb}, \mathrm{Zn}$, $\mathrm{Cd}$ and $\mathrm{Hg}$ contents when a surface precipitate layer presented were much lower than those without a surface layer. The amount of $\mathrm{Cr}$ increased with 
aging, whose rate was also lower when the surface precipitate layer was present. This observation follows from the fact that the added mass transfer barrier of $\mathrm{CO}_{2}$ or $\mathrm{O}_{2}$ at the air-water surface influences the occurrence of subsequent chemical reactions.

A simple estimate of the rate of mass transfer revealed that the rate-controlling step at $L / S=10$ was not the diffusion of $\mathrm{CO}_{2}$ into ash particles, as proposed by Fernández Bertos et al. (2004). The most important chemical reactions occur in the bulk suspension rather than on the surface of the ash particles or inside the ash particles. The dissolution and diffusion of $\mathrm{CO}_{2}$ in the bulk solution are the ratelimiting steps in the carbonation of ash suspension $(L / S=10)$. However, in $L / S=0.25$ tests, the ratelimiting step was the rate of dissolution of metals from ash particles. The water content is a very important process factor, whose distribution in the sample, along with the resulting competition between the carbonate ion flux and the heavy metal flux, determines the reaction time required during natural aging process.

\section{Acknowledgments}

We thank Shanghai Council of Science and Technology for the financial support through the project "Research on beneficial use of MSW incineration residues and its demonstration project" (032312043).

\section{Appendix A}

$D \quad$ the diffusion coefficient of $\mathrm{CO}_{2}$ in water at $25^{\circ} \mathrm{C}, 1.96 \times 10^{-9} \mathrm{~m}^{2} \mathrm{~s}^{-1}$;

E Henry coefficient, $\mathrm{Pa}$, for $\mathrm{CO}_{2}$ in water it is $1.66 \times 10^{8} \mathrm{~Pa}$ at $25{ }^{\circ} \mathrm{C}$;

$K_{\text {sp }} \quad$ the solubility-product constant;

$N_{\mathrm{A}, \mathrm{CO}_{2}}$ the diffusion rate of dissolved $\mathrm{CO}_{2}$ transferred from top surface to the bottom residues layer;

$\mathrm{N}_{\mathrm{Ca}}^{2+}$ the diffusional flux of $\mathrm{Ca}^{2+}$ from the bottom to top surface;

$L \quad$ thickness of water above the ash layer, 0.08 $\mathrm{m}$ here;

$p_{\mathrm{e}} \quad \mathrm{CO}_{2}$ partial pressure, $30 \mathrm{~Pa}$ in air;

$x_{0} \quad \mathrm{CO}_{2}$ mol fraction.

\section{References}

Bin-Shafique S, Walton JC, Gutierrez N, Smith RW, Tarquin AJ. Influence of carbonation on leaching of cementitious wasteforms. J Environ Eng 1998;124(5):463-7.

Bone BD, Knox K, Picken A, Robinson HD. The effect of carbonation on leachate quality from landfilled municipal solid waste (MSW) incinerator residues. In: Christensen TH, Cossu R, Stegmann R, editors. Proc Sardinia 2003, Ninth Waste Management and Landfill Symposium 6-10 October 2003. Italy: S. Margherita di Pula (CA); 2003.

Cai SH, Huang SY, Zhang YR. Elemental inorganic chemistry. Guangzhou: Zhongshan University Press; 1998. 290-291 pp. [in Chinese].

Ecke H, Menad N, Lagerkvist A. Treatment-oriented characterization of dry scrubber residue from municipal solid waste incineration. Mater Cycles Waste Manage 2002;4(2):117-26.

Ecke H, Menad N, Lagerkvist A. Carbonation of municipal solid waste incineration fly ash and the impact on metal mobility. $\mathrm{J}$ Environ Eng 2003;129(5):435-40.

Fernández Bertos M, Li X, Simons SJR, Hills CD, Carey PJ Investigation of accelerated carbonation for the stabilization of MSW incinerator ashes and the sequestration of $\mathrm{CO}_{2}$. Green Chem 2004;698:428-36.

He PJ, Zhang H, Zhang CG, Lee DJ. Characteristics of air pollution control residues of MSW incineration plant of Shanghai. J Hazard Mater 2004;B116:229-37.

He PJ, Cao QK, Feng JH, Xia YQ. Source characteristics of byproducts of municipal solid waste incinerator. Environ Eng 2005;23(4):56-9 [in Chinese, with English abstract].

Hjelmar O, Birch H. Treatment of air pollution control residues from MSW incinerators prior to landfilling. In: Christensen TH, Cossu R, Stegmann R, editors. Proc Sardinia 97, Sixth Waste Management and Landfill Symposium, 13-17 October 1997. Italy: S. Margherita di Pula (CA); 1997. p. 535-44.

Kim SY, Matsuto T, Tanaka N. Evaluation of pre-treatment methods for landfill disposal of residues from municipal solid waste incineration. Waste Manage Res (21):416-23.

Macias A, Kindness A, Glasser FP. Impact of carbon dioxide on the immobilization potential of cemented wastes: chromium. Cem Concr Res 1997;27(2):215-25.

Reijnders L. Disposal, uses and treatments of combustion ashes: a review. Resour Conserv Recycl 2005;43:313-36.

Sabbas T, Polettini A, Pomi R, Astrup T, Hjelmar O, Mostbauer P, et al. Management of municipal solid waste incineration residues. Waste Manage 2003;23:61-88.

Shimaoka T, Miyawaki K, Soeda M, Hanashima M, Yoshida $\mathrm{T}$, Uchida $\mathrm{T}$, et al. Mechanisms for the aging-induced reduction of lead solubility in scrubber residues from municipal solid waste combustion. Waste Manage Res 2002;20(1):90-8.

State Environmental Protection Administration of China. Identification standard for hazardous wastes - identification for extraction causticity, GB50851-1996. [in Chinese].

State Environmental Protection Administration of China. Identification standard for hazardous wastes - identification for extraction procedure toxicity, GB50853-1996. [in Chinese]. 
State Environmental Protection Administration of China. Solid waste- extraction procedure for toxicity of solid waste - horizontal vibration method, GB50861-1997. [in Chinese].

Valls S, Vàzquez E. Accelerated carbonation of sewage sludgecement-sand mortars and its environmental impact. Cem Concr Res 2001;31:1271-6.

Venhuis MA, Reardon EJ. Vacuum method for carbonation of cementitious wasteforms. Environ Sci Technol 2001;35: $4120-5$.
Walton JC, Bin-Shafique S, Gutierrez N, Smith R, Tarquin A. Role of carbonation in transient leaching of cementitious wasteforms. Environ Sci Technol 1997;31:2345-9.

Zheng LM, Zhu SY. Element chemistry. Beijing: Chemical Industry Press; 1999. 211-212 pp. [in Chinese]. 